patients in the ampicillin $1 \mathrm{~g}$ groups and ampicillin $2 \mathrm{~g}$ groups when febrile patients with only pneumococcal pneumonia were compared (Fig. 2).

Of all febrile pneumonia cases receiving prednisolone (groups 2 and 4 ) the difference in resolution of temperature between those receiving and not receiving prednisolone did not reach statistical significance on day $3, x^{2}=3.72(0.10>P$ $>0.05$ ) (Fig. 3). The results suggest, however, the possibility of an effect, and the trend is repeated when the mildly ill patients are excluded. Febrile pneumococcal pneumonia patients only are shown in Fig. 4, and again the patients receiving prednisolone (groups 2 and 4 ) appear to become afebrile more quickly although this is not statistically significant.

Clearance of Initial Pathogens. - The time taken for the organism found in the sputum or laryngeal swab to disappear is shown in Table $\mathrm{V}$. There is no important difference between the groups.

Maximum Radiological Clearing.-The time in which maximum clearing was achieved is shown in Table VI. There is no important difference between the groups.

\section{Discussion}

The groups of patients receiving $2 \mathrm{~g}$ ampicillin (groups 3 and 4) were slightly more favoured as regards previous respiratory infection and had fewer positive blood cultures. These groups, however, were slightly less favoured in having more accompanying viral and klebsiella infections, which would not be expected to respond to ampicillin therapy. The results in general were if anything less good in the $2 \mathrm{~g}$ ampicillin groups. This is shown when comparing the temperature response where the patients in groups 3 and 4 did less well than those in groups 1 and 2 , the difference being statistically significant on day 6 (Fig. 1). There was no important difference in the rate of clearance of pathogens from the sputum or of shadowing on the chest $x$-ray film. Of the patients in groups 3 and $4,11 \%$ developed rashes. No rashes developed in the patients in groups 1 and 2 . The advantages to the $1 \mathrm{~g}$ group, although statistically significant in respect of pyrexia, are unlikely to represent a real superiority to the $2 \mathrm{~g}$ dose, but certainly do not support the view that $2 \mathrm{~g}$ is better than $1 \mathrm{~g}$. Moreover, all the rashes occurred in the $2 \mathrm{~g}$ groups. The higher dose is of course more expensive.

When comparing patients receiving ampicillin and predniso- lone with those taking ampicillin alone, patients on prednisolone became afebrile more rapidly (Figs. 3 and 4). This was not found to be statistically significant although it was nearly so. No difference in the rates of clearance of pathogens or of chest $\boldsymbol{x}$-ray appearances was noted. No evidence of deleterious effects was noted in patients receiving the prednisolone.

It is of interest that patients developed ampicillin rashes in spite of taking prednisolone, which might have been expected to dampen the allergic response. However, before concluding that prednisolone should be used as routine treatment in pneumonia it would be wise to carry out a further trial involving a larger number of patients. It should also be remembered that patients with diabetes mellitus or symptoms of recent peptic ulceration were not given prednisolone in this present trial.

Our thanks are due to the following doctors and nurses who played a major part in the day-to-day conduct of the trial: Drs. A. J. Akhtar, I. M. E. Anderson, D. Asbury, D. Bainbridge, N. Beattie, J. A. O. Besson, R. C. Borthwick, B. Bowen, W. B. Buie, D. C. Cameron, S. J. Cameron, J. Campbell, A. J. Carter, W. L. Caulfield, R. A. Clark, T. J. Clark, S. J. Collingham, J. Y. F. Choo-Kang, G. K. Crompton, D. Cumberland, G. B. Drummond, M. J. B. Farebrother, E. M. K. Finlayson, D. H. Franklin, J. Friend, M. George, A. Glynne, D. H. Goose, W. Gray, D. Hardy, C. Hawkes, E. Hope, F. F. N. Ihekwaba, H. M. Johnstone, G. R. Jones, A. B. Kay, S. Korbel, T. Kurian, S. Lindo, D. G. Littlewood, D. M. Lloyd, J. Longstaff, J. W. McCrone, T. H. MaDonald, R McFadzean, D. N. S. Malone, F. M. Marr, J. Medway, R. E. Micallef, I. Mitchell, P. L. Moffat, B. Muir, J. Ormrod, S. Pickens, F. D. Pilditch, J. V. Prosser, A. Proudfoot, A. Raeburn, P. Sanders, G. I. S. Sandor, C. C. Smith, M. Taylor, N. R. Ward, M. Webb, M. Whitmore, D. Wood, and A. R. Wright, and Sisters M. Allan, J. McLeod, S. Menzies, M. Nicol, E. Olsson, J. O'Malley, E. Simpson, and D. Tinsdale. We are also grateful to the many technicians of the Wellcome Laboratory, City Hospital, and of the Central Microbiological Laboratories for technical help.

We are particularly grateful to Professor John Crofton and Dr. Eileen Crofton for their advice and criticism. We also thank Miss M. C. Drummond, who acted as co-ordinating secretary of the trial, and Mrs. L. Scott for secretarial help. This study was supported by an anonymous gift to the Department of Respiratory Diseases, University of Edinburgh.

\section{References}

Crofton, E. C. (1966). British Medical fournal, 1, 1329.

Calder, M. A., McHardy, V. U., and Schonell, M. E. (1970). Lancet, 1, 5.

\title{
An Assessment of Postoperative Outpatient Cases
}

\author{
T. W. OGG \\ British Medical fournal, 1972, 4, 573-576
}

\section{Summary}

A total of 100 outpatients in the North-East of Scotland were given a simple anaesthetic of propanidid, nitrous oxide, oxygen, and halothane. The study was undertaken to assess what happened to patients when they left hospital after outpatient surgery. An outpatient questionnaire was used, and results show that $31 \%$ of patients journeyed home unaccompanied by a responsible person, $73 \%$ of car owners drove within 24 hours of the operation, and $9 \%$ drove themselves home. Postoperative

Royal Infirmary, Aberdeen

T. W. OGG, M.B., F.F.A.R.C.S., Senior Registrar in Anaesthetics symptoms of drowsiness (26\%), headache $(27 \%)$, nausea $(22 \%)$, and dizziness $(11 \%)$ were recorded, and a higher incidence of symptoms was recorded when surgery exceeded 15 minutes. A new form for outpatient operative procedures in Aberdeen has been devised with modern legal implications in mind.

\section{Introduction}

In British hospitals day surgery is an accepted routine, and as a sequel to the study performed by Fahy and Marshall (1969) it was decided to assess the effects of a simple anaesthetic technique on outpatients in the Aberdeen area undergoing minor surgery. The object was to estimate the anaesthetic postoperative morbidity, and to clarify what happened once these patients left the hospital confines. 


\section{Materials and Methods}

A total of 100 outpatients attending the Royal Infirmary and Woolmanhill Casualty Department, Aberdeen, for minor surgical procedures were given a standard anaesthetic of propanidid $7 \mathrm{mg} / \mathrm{kg}$, nitrous oxide, and oxygen, with supple-

FIG. 1-Questionnaire form given to outpatients after operation.

$\begin{array}{ll} & \text { Outpatient Questionnaire } \\ \text { Section B } & \text { Case No. }\end{array}$

An attempt is being made to assess the effects of an outpatient operation on patients in the North-East of Scotland. Your reply will be treated confidentially. Please enclose the completed questionnaire be treated confidentially. Please enclose the
in the stamped addressed envelope supplied.

INSTRUCTIONS: Please encircle the correct answer.

(1) Was this your first outpatient operation? ..

YES/NO

(2) Were you advised by the hospital

(a) To have no food or fluids for 4 hours prior to the

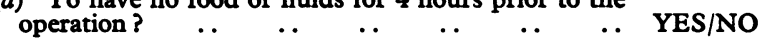

(b) Not to drive a car after the anaesthetic ? .. .. YES/NO

(c) To avoid taking alcohol the day of the operation? YES/NO

(3) Approximately how long after your anaesthetic were you allowed to leave hospital ? .. .. ..

(4) Were you accompanied home by a responsible $\begin{array}{llllllll}\text { person ? } & . & \ldots & \ldots & \ldots & \ldots & \ldots\end{array}$

(5) Was the only person to accompany you home a taxi $\begin{array}{lllll}\text { or ambulance driver ? } & \cdots & \ldots & \ldots & \ldots\end{array}$

(6) Did you develop any of the following after your hospital discharge?
(a) Muscle aches or stiffness
$\cdots$
. YES/NO
.. YES/NO

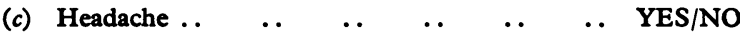

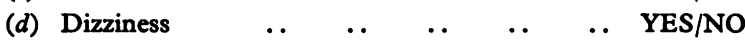

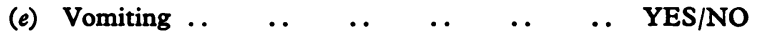
(f) Nausea (a sick feeling but no vomiting)... .. Y YES/NO

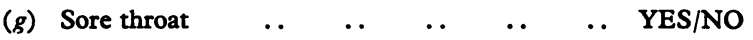
(h) Pain at the site of anaesthetic injection .. . . Y YES/NO

(7) For how long were you off work or school?

(8) If you are a housewife were you able to do your housework and look after the family during the two days after the operation?

(9) Did you have to call your doctor in ? $\quad . \quad \ldots$ YES/NO If YES give brief details why:

(10) Did you drink any alcohol 24 hours after the opera$\begin{array}{llllllll}\text { tion? } . . & \ldots & \ldots & \ldots & \ldots & \ldots & \ldots & \text { YES/NO }\end{array}$

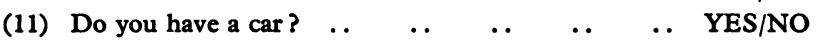

(12) Did you drive your car?

(a) Within 12 hours of the operation? $\quad$. $\quad \ldots \quad$ YES/NO

(b) Within 24 hours of the operation ? $\quad \ldots \quad \ldots$ YES/NO

(13) Were you involved in any minor or major traffic If YES please give brief details:

(14) Have you ever had:

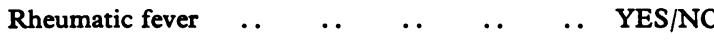

$\begin{array}{llllllll}\text { Migraine } & \ldots & \ldots & \ldots & \ldots & \ldots & \ldots & \text { YES } / N O\end{array}$

$\begin{array}{llllllll}\text { Diabetes } & \ldots & \ldots & \ldots & \ldots & \ldots & \ldots & \text { YES/NO }\end{array}$

$\begin{array}{llllllll}\text { Asthma } & \ldots & \ldots & \ldots & \ldots & \ldots & \ldots & \text { YES/NO }\end{array}$

High blood pressure $\quad \ldots \quad \ldots \quad \ldots \quad \ldots \quad \ldots$ YES/NO

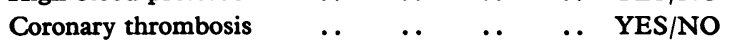

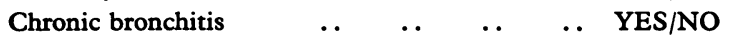

(15) Were you taking any medicine for these conditions at the time of the operation? $\quad \ldots \quad$. $\quad \ldots$ YES/NO

(16) Did you have:

(a) Anything to eat or drink $\quad \ldots \quad \ldots \quad$. . $\quad$ YES/NO

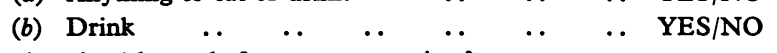

during the 4 hours before your operation?

(17) Should it be required would you like to have a similar anaesthetic again? .. $\quad . . \quad \ldots \quad$.. $\quad$.. YES/NO

(18) Please state any complaints you have about your treatment in hospital: ments of halothane. On completion of the operation the patients were visited, consent was obtained, and each given a cyclostyled questionnaire (Fig. 1) with instructions to read the questionnaire 48 hours postoperatively, to complete the form by encircling the appropriate Yes/No answers, and to return the form in the stamped addressed envelope provided.

In response to these instructions $99 \%$ of the patients in the series returned the questionnaires promptly.

\section{Results}

Altogether, $57 \%$ of the patients in the study (30 females and 70 males, average age 45.5 years) had had their first outpatient operation. The operations performed are shown in Table I. The age distribution of the patients and the duration of postoperative stay in hospital are shown in Tables II and III. In reply to question 2 , all patients were advised not to have food or fluids for four hours preoperatively, $81 \%$ were advised not to drive within 24 hours of the operation, and $48 \%$ were told not to take alcohol on the day of the operation.

Postoperative symptoms recorded in answer to question 6 are shown in Table IV. Particular notice should be drawn to the extent of drowsiness $(26 \%)$, headache $(27 \%)$, nausea $(22 \%)$, and dizziness $(11 \%)$. The symptoms of those patients unaccompanied home are detailed in Table V, and Table VI

TABLE I-Surgical Procedures in 100 Outpatient Operations

Minor orthopaedic surgery

\begin{tabular}{ll|l}
.. & 27 & Cystoscopy and retrograde pyelo-
\end{tabular} Cystoscopy $\begin{array}{lll}\text { Craphy } & \\ \text { Vystoscopy and bougienage } & \ldots & 5 \\ \text { Vasectomy }\end{array}$

TABLE II-Age Distribution of Patients in the Series

\begin{tabular}{l|c|c|c|c|c|c|c}
\hline Age in years .. & $10-19$ & $20-29$ & $30-39$ & $40-49$ & $50-59$ & $60-69$ & $70-79$ \\
No. of patients & 12 & 15 & $\begin{array}{c}80 \\
20\end{array}$ & $\begin{array}{c}17 \\
8\end{array}$ \\
\hline
\end{tabular}

TABLE III-Duration of Postoperative Stay in Hospital

\begin{tabular}{l|c|c|c|c|c|c|c|c}
\hline $\begin{array}{c}\text { Stay in } \\
\text { hospital } \\
\text { (minutes) } \\
\text { No. of patients }\end{array}$ & $0-29$ & $20-59$ & $\begin{array}{c}60-89 \\
10\end{array}$ & $\begin{array}{c}90-119 \\
22\end{array}$ & $\begin{array}{c}120-149 \\
10\end{array}$ & $\begin{array}{c}150-179 \\
14\end{array}$ & $\begin{array}{c}180-209 \\
6\end{array}$ & $\begin{array}{c}210-239 \\
25\end{array}$ \\
\hline
\end{tabular}

TABLE IV-Postoperative Symptoms of the 100 Outpatients Within the First 48 Hours

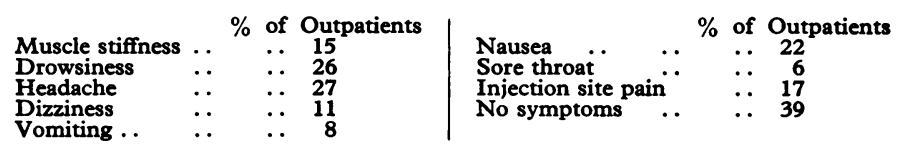

TABLE v-Postoperative Symptoms in Unaccompanied Outpatients

\begin{tabular}{|c|c|c|c|c|c|c|c|}
\hline & & & & & \multicolumn{3}{|c|}{ Returned Home Alone by: } \\
\hline & & & & & $\underset{(n=6)}{\text { Taxi }}$ & $\underset{(n=16)}{\text { Bus }}$ & $\underset{(n=9)}{\operatorname{Car}}$ \\
\hline $\begin{array}{ll}\text { Muscle stiffness } & \ldots \\
\text { Drowsiness } & \ldots \\
\text { Headache } & \ldots\end{array}$ & $\begin{array}{l}\ldots \\
\because \\
\because \\
\cdots \\
\cdots\end{array}$ & $\begin{array}{l}\ldots \\
\because \\
\because \\
\because \\
\cdots \\
\cdots\end{array}$ & $\begin{array}{l}\ldots \\
\because \\
\because \\
\cdots \\
\cdots \\
\therefore\end{array}$ & $\begin{array}{l}\cdots \\
\cdots \\
\cdots \\
\cdots \\
\cdots \\
.\end{array}$ & $\begin{array}{l}0 \\
0 \\
1 \\
0 \\
0 \\
0 \\
0 \\
0\end{array}$ & $\begin{array}{l}1 \\
3 \\
3 \\
2 \\
0 \\
2 \\
1 \\
1\end{array}$ & $\begin{array}{l}1 \\
3 \\
4 \\
3 \\
1 \\
2 \\
0 \\
2\end{array}$ \\
\hline
\end{tabular}

TABLE VI-Postoperative Symptoms and Sex Incidence of the 100 Outpatients

\begin{tabular}{|c|c|c|c|c|}
\hline & $\begin{array}{l}\text { No. in } \\
\text { Series }\end{array}$ & $\begin{array}{l}\text { No. with } \\
\text { Symptoms }\end{array}$ & $\begin{array}{l}\text { Percentage } \\
\text { of Total }\end{array}$ & $\begin{array}{c}\text { Average Age } \\
\text { (years) }\end{array}$ \\
\hline $\begin{array}{l}\text { Female } \\
\text { Male }\end{array}$ & $\begin{array}{l}30 \\
70\end{array}$ & $\begin{array}{l}24 \\
33\end{array}$ & $\begin{array}{l}80 \\
47\end{array}$ & $\begin{array}{l}39 \\
44\end{array}$ \\
\hline
\end{tabular}


shows that symptoms were more prevalent in females $(80 \%)$ than males $(47 \%)$. It was the younger females, average age 39 years, who complained most. Correlation of the duration of operation with the incidence of symptoms is shown in Table VII, and it is shown that when surgery exceeded 15 minutes there was an increased number of symptoms $(62 \%)$.

TABLE VII-Postoperative Symptoms and Duration of Surgery in Minutes

\begin{tabular}{c|r|r|r|r|c|c}
\hline \multirow{2}{*}{ Duration of Surgery } & \multicolumn{4}{|c|}{ No. of Symptoms } & No. of Patients & $\begin{array}{c}\text { Percentage } \\
\text { Anaesthetized } \\
\text { of Symptoms }\end{array}$ \\
\cline { 2 - 7 } & 1 & 2 & 3 & 4 & 79 & 57 \\
\hline$<15 \mathrm{~min}$ & 20 & 11 & 8 & 7 & 21 & 62 \\
\hline
\end{tabular}

Of the 20 housewives in the study, four admitted that they were unable to pursue their normal household duties. The questionnaire disclosed that $5 \%$ of patients had to call on the services of their general practitioner (question 9). The complaints were mainly of postoperative pain and urinary retention. Six per cent, of the patients drank alcohol within 24 hours of the operation.

In reply to the questions asking if a car was owned or driven (questions 11 and 12 ), $41 \%$ replied yes. Of those, $30 \%$ drove within 12 hours postoperatively, $43 \%$ drove within 24 hours, and $27 \%$ obeyed instructions and did not drive. Nine per cent. of the patients in the series admitted that they had driven themselves home alone. No traffic offences were recorded. Altogether, $34 \%$ of patients had previous medical histories of a major nature (Table VIII), and $8 \%$ were undergoing treatment

TABLE VIII-Associated Medical Condition of the 100 Outpatients

Migraine.

Asthma

Hypertension

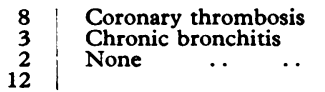

for these illnesses. In reply to question $16,1 \%$ had eaten and $2 \%$ had drunk in the four hours before surgery. Three per cent. of patients indicated that they would not like the same anaesthetic again.

\section{Discussion}

About 4,000-5,000 outpatient operations are performed annually in Aberdeen, and it was decided to assess the effects of such procedures on patients postoperatively. The outpatient questionnaire was selected as the method for study following the observations of a Newcastle series that it was a valuable research tool. An attempt has been made to go a little further, and information has been collected to assess how these outpatients journeyed home, their postoperative stay in recovery, and their symptoms within $\mathbf{4 8}$ hours of surgery.

Once a patient has been instructed by the hospital as regards food, fluids, and driving, technically the matter is outwith the control of the surgeon and the anaesthetist. Many experienced anaesthetists will agree that a few of their day surgery cases pay little attention to the preoperative instructions issued. The ultimate responsibility, however, must rest with the board of management of the hospital concerned, and it is noted that there is a current upward trend in claims against medical establishments. Whereas in 1961 claims amounted to $£ 200,000$, in 1971 they totalled $£ 3 \frac{1}{4} \mathrm{~m}$.

There was a favourable response to the outpatient questionnaire, a return rate of $99 \%$, and from the results doubts must be cast on the existing instructions sent to day cases in the Aberdeen area. It does appear that most patients were kept in recovery for a sufficient period of time. The $31 \%$ of cases who journeyed home alone, however, must give rise to some concern, and the $9 \%$ who drove themselves home cannot be dismissed. From a breakdown of their symptoms they were clearly unfit to drive (Table V), and urgent steps should be taken to stop these practices. The obvious risk to the general public must be taken into account, and with 4,750 outpatient operations performed annually some unfortunate accident may occur if current trends are allowed to continue.

The number of car owners who disregarded hospital instructions is another important finding. Altogether, $73 \%$ of all car owners drove within 24 hours, $30 \%$ within 12 hours. At this point mention should be made of a patient who drove himself 15 miles $(24 \mathrm{~km})$ home after a cystoscopy and bougienage, and thereafter continued to drive a bus load of passengers to Dundee and back on the same day-a distance of 95 miles $(153 \mathrm{~km})$. This patient was not included in the present study.

Patients complained of headache in $27 \%$ of instances. Thomas (1963) stated that headache was the commonest postoperative complaint $(15 \%)$ after minor gynaecological surgery. Hannington-Kiff (1969) reported that migraine sufferers had a higher incidence of headache but premedicated day cases suffered less. Tyrrell and Feldman (1968) found that by excluding the popular modern anaesthetic halothane from their technique an incidence of only $2.7 \%$ headache was recorded.

From the present results junior anaesthetists should notice the number of patients $(34 \%)$ who present for day surgery with significant previous medical histories. Of these, $8 \%$ were on such treatments as antihypertensive drugs, beta-adrenergic blockers, steroids, bronchodilators, digitalis, and diuretics. These findings should impress on anaesthetic departments not to delegate the responsibility of such cases to a very junior anaesthetist. Furthermore, it should be stressed that in every location for outpatient surgery adequate facilities for intubation, resuscitation, and suction must be provided.

To conclude, there exists a real problem of how to correct certain human failings and ensure the safety of both patients and the general public. In most hospitals day surgery has decided advantages over the more expensive system of inpatient treatment. Since the claims against medical personnel are rising yearly a new outpatient form (Fig. 2) has been

FIG. 2-Proposed new outpatient form before surgery.

1. I $\ldots \ldots \ldots \ldots \ldots \ldots \ldots \ldots \ldots \ldots \ldots$ consent to the... operation of ....................... being performed... upon me.

2. As instructed:

(i) I have had no food nor fluids for $\mathbf{4}$ hours pre-operatively

(ii) I have agreed not to drive any vehicle nor operate machinery for 24 hours post-operatively

(iii) I have agreed not to consume alcohol for 24 hours postoperatively

Date................. Signature.................

Medical Witness.....................

recommended. This form would have to be read and signed in the presence of a medical witness by all patients undergoing minor surgery. Any attempt to reduce outpatient surgery in British hospitals would be unacceptable in most instances, but perhaps surgeons could expertly assess which patients should undergo such surgery, especially in view of the finding that $34 \%$ of all cases had a major medical illness. In this context an anaesthetic outpatient session preoperatively could prove a profitable advancement in patient care.

It is agreed, as in previous studies, that the outpatient questionnaire has proved a useful research tool. As in the Newcastle series, $80 \%$ of females and $47 \%$ of males complained of postoperative symptoms. It is hoped that other hospitals may adopt this form of study to assess the situation in their own region. 
Thanks are expressed to the patients who co-operated in this study, and to the consultant surgeons, Mr. W. H. Garvie and Dr. D. M. Proctor, in the departments involved in this work. The project was financed by a grant from the North-East of Scotland Regional Hospital Board's Clinical Research Fund.
References

Fahy, A., and Marshall, M. (1969). British fournal of Anaesthesia, 41, 433. Thomas, E. (1963). British fournal of Anaesthesia, 35, 327.

Hannington-Kiff, J. G. (1969). British fournal of Anaesthesia, 41, 401 Tyrrell, M. F., and Feldman, S. A. (1968). British Journal of Anaesthesia,
40,

\section{Multicentre, Short-term Therapeutic Trial of Disodium Cromoglycate, With and Without Prednisone, in Adults with Asthma*}

\author{
T. GEBBIE, \\ E. A. HARRIS, \\ T. V. O'DONNELL,
}

British Medical fournal, 1972, 4, 576-580

\section{Summary}

A total of 117 asthmatic patients were studied in a doubleblind, cross-over trial with half-periods of three weeks in which disodium cromoglycate (D.S.C.G.) was compared with an inactive preparation. D.S.C.G. improved spirometric measurements, at a very high level of statistical significance, more than did placebo. The mean advantage of D.S.C.G. was less than $10 \%$ after three weeks. Symptomatic improvement by D.S.C.G. was small though significant; it was not correlated with spirometric improvement. A history of chronic cough was the only clinical characteristic associated with a better-than-average spirometric response to D.S.C.G.

\section{Introduction}

The effects of disodium cromoglycate (D.S.C.G.) on the respiratory manifestations of antigen-antibody reactions, both in animals and in man, have been striking (Altounyan, 1968; Pepys et al., 1968). In contrast the use of D.S.C.G. in the treatment of adult patients with asthma has produced less convincing results (Grant et al., 1967; Kennedy, 1967; Altounyan and Howell, 1969; Gianoutsos and O'Donnell, 1969; Bernstein et al., 1971). In particular, objective evidence of improvement has been poorly related to symptomatic improvement, although in many trials the individual patient's potential capacity for spirometric improvement has not been clearly indicated. On the other hand, there is evidence (Read and Rebuck, 1969) that in patients receiving continuous treatment with a corticosteroid drug, its dose can be reduced when D.S.C.G. is administered.

In the clinical trial reported below the effect of D.S.C.G. was compared with that of an inactive preparation before and after a three-day course of prednisone in adult patients with chronic asthma.

* Report on a trial co-ordinated by the Clinical Trials Committee of the Medical Research Council of New Zealand.

Wellington Hospital, Wellington, New Zealand

T. GEBBIE, M.B., F.R.A.C.P., Physician

Clinical Physiology Department, Green Lane Hospital, Auckland, New Zealand

E. A. HARRIS, M.D., F.R.C.P., Physician-in-Charge

University of Otago, Dunedin, New Zealand

T. V. O'DONNELL, M.D., F.R.C.P., Professor of Medicine

G. F. S. SPEARS, M.SC., DIP.MATH.STATS., Department of Preventive and Social Medicine

\section{G. F. S. SPEARS}

\section{Patients and Methods}

The general criterion for inclusion in the trial was chronic asthma of moderate severity. "Chronic asthma" was defined by clinical and spirometric evidence of wheeze and airways obstruction of fluctuating degree for at least six months. "Moderate severity" demanded evidence that at some time during the three months before the trial the forced expiratory volume in 1 second $\left(\mathrm{FEV}_{1}\right)$ had increased by at least $20 \%$ in response to an adequate dose of isoprenaline, orciprenaline, or salbutamol aerosol. Patients with chronic bronchitis (defined as a productive cough for at least three consecutive months for at least two successive years (Medical Research Council, 1965), were not excluded, but an attempt was made to include a reasonable number of patients who did not give such a history. Previous treatment with D.S.C.G. was no bar to inclusion, provided that no such treatment had been given for at least eight weeks before the trial began. Otherwise, all patients continued to take their usual treatment according to previously established indications throughout the trial. In 58 of the 117 patients selected asthma had been thought to be of such severity that continuing corticosteroid therapy had been prescribed.

\section{DESIGN OF TRIAL}

The trial was preceded by one week during which preliminary history-taking and examination were completed, and in which the procedure was explained to the patients, and spirometric manoeuvres were practised by them.

The trial itself was conducted simultaneously in all eight centres during the six weeks from 1 March to 7 April 1971, just past the peak of the summer season in the South Pacific area. During the first three weeks either $20 \mathrm{mg}$ disodium cromoglycate (D.S.C.G.) or an inactive control substance $(15 \mathrm{mg}$ lactose, $5 \mathrm{mg}$ sodium sulphate) was given by Spinhaler at 07.00 , $12.00,17.00$, and 22.00 hours. During the second three weeks the alternative substance was given at these hours, the order for each patient being randomly determined. The days of the trial will be referred to as D.S.C.G. 1 to 21 and placebo 1 to 21 , irrespective of the order in which the preparations were given. On days D.S.C.G. 10, 11, and 12, and placebo 10,11 , and 12, prednisone was administered (10 $\mathrm{mg}$ given by mouth every eight hours). The patients were not aware of the activity of the preparations they received. Many patients detected a difference between D.S.C.G. and the placebo, but all were told that the purpose of the trial was "to compare two drugs." The observers were not aware of whether D.S.C.G. or the placebo was being taken, but knew that on days 10,11 , and 12 an active steroid drug was being given. 